\title{
CHARACTERIZATION OF BONE CELLS OBTAINED FROM THE CALVARIA OF NEONATAL RATS (OSTEO-1) AFTER SERIAL SUBCULTURE
}

\author{
Adriane Yaeko TOGASHI ${ }^{1}$, Fabiano Ribeiro CIRANO ${ }^{2}$, Márcia Martins MARQUES ${ }^{3}$, \\ Francisco Emílio PUSTIGLIONI ${ }^{4}$, Luiz Antonio Pugliesi Alves de LIMA ${ }^{5}$
}

\begin{abstract}
1-DDS, MSc, Assistant Professor, Department of Periodontology and Implantology, UNIOESTE, Cascavel - PR.
2- DDS, MSc, Assistant Professor, Department of Periodontology, UNIP, São Paulo - SP.

3- DDS, PhD, Associate Professor, Department of Restorative Dentistry, University of São Paulo, São Paulo - SP.

4- DDS, PhD, Chair Professor, Department of Periodontology, University of São Paulo, São Paulo - SP.

5- DDS, PhD, Associate Professor, Department of Periodontology, University of São Paulo - São Paulo - SP.
\end{abstract}

Corresponding address: Dra. Adriane Yaeko Togashi - Rua Carlos de Carvalho, 3950/801 - 85810-080 - Cascavel - PR - e-mail: aytogashi@unioeste.br ou togashi@usp.br - Phone: 5545 8822-2922 - 554532227615.

Received: February 15, 2007 - Modification: March 9, 2007 - Accepted: July 2, 2007

\begin{abstract}
$\Gamma_{\text {he }}$

he objective of the present study was to characterize bone cells grown in two culture media, and to determine the effective concentration of OP-1 on the growth of osteo-1 cells. Subcultured rat bone cells (osteo-1) were grown in alpha-modified Eagle's minimal essential medium ( $\alpha$-MEM) and Dulbecco's modified Eagle's medium (DMEM) and total protein content, alkaline phosphatase activity and the formation of mineralized nodules were evaluated after 7, 14 and 21 days. Cells were exposed to different concentrations of rhOP-1 for 1, 3, 5 and 7 days and compared with an untreated control. Osteo-1 cells presented a significant increase in alkaline phosphatase activity and calcium deposits were observed at 21 days. Cells treated with 10 and $20 \mathrm{ng} / \mathrm{mL}$ rhOP-1 for $24 \mathrm{~h}$ showed a significant increase in cell viability when compared to control. Osteo-1 cells cultured on DMEM demonstrated an osteoblastic phenotype as indicated by high alkaline phosphatase activity and the presence of calcified nodules. The results suggest that low concentrations of OP-1 may promote an osteogenic effect on osteo-1 cells.
\end{abstract}

Uniterms: Osteoblasts; Cell culture techniques; Cell differentiation; Calcification, physiological.

\section{INTRODUCTION}

Well-characterized osteoblast cultures provide an adequate model for the study of cell behavior and for the determination of biological aspects of the interaction between materials and bone tissue. However, when isolated, bone cell lineages lose their morphological identity ${ }^{22}$. Various protocols have been established for the characterization of isolated bone cells, including the determination of the level of alkaline phosphatase (AP) activity, specific bone proteins (osteonectin and osteocalcin) and type I collagen ${ }^{4,18}$. The ability of isolated bone cells to produce calcifications also indicates an osteoblastic phenotype ${ }^{2,19,26}$.

Deboni, et al. ${ }^{10}$ (1996) identified and characterized cells obtained from the calvaria of neonatal albino Wistar rats, called osteo-1 cells. After first passage, phenotypic differentiation of the cultures was induced by supplementation of the medium with $10 \mathrm{mM}$ sodium $\beta$ - glycerophosphate, $50 \mathrm{ig} / \mathrm{mL}$ ascorbic acid and $10^{-8} \mathrm{M}$ dexamethasone. The authors confirmed the osteoblastic nature of the primary cultured cells based on the analysis of morphology, the presence of AP activity, production of calcified nodules, and the immunocytochemical expression of collagen (type I collagen) and non-collagen (osteonectin and bone sialoprotein II) bone proteins. Since then, osteo1 cells have been subcultured and frozen in various experiments ${ }^{15}$. However, no study has evaluated the maintenance of the cellular characteristics that lead to cell differentiation over time.

Because of the small amount of biological material available from the first culture, various cell passages are generally necessary to obtain a sufficient number of cells for experiments ${ }^{11}$. In this respect, the maintenance of the osteoblastic phenotype over serial subcultures is essential. Some studies have shown the loss of the osteoblastic phenotype when diploid cells are subcultured ${ }^{8,27}$.

The expression of a cellular phenotype in culture also 
depends on the biological material used, its manipulation and culture conditions such as culture medium, time of growth and the presence of components that influence cell proliferation and differentiation ${ }^{7,9}$. Coelho, et al. ${ }^{8}$ (2000), analyzing human bone marrow cells, showed similar cell proliferation in two different culture media but AP activity and the ability to form mineralized deposits were lower in the DMEM culture. In both experimental situations, osteoblastic parameters were strongly reduced on cell passage, particularly from the first to the second subculture.

Bone morphogenetic protein (BMP) plays a crucial role in the growth and differentiation of a variety of cell types including osteoblasts ${ }^{5}$. Osteogenic protein-1 (OP-1) promotes the maturation of committed cells to differentiate into osteoblasts, increases the expression of osteoblast marker genes and bone-like nodule formation in calvariaderived cells, and promotes the differentiation of bone marrow cells into osteoblastic cells ${ }^{13,20}$.

Sampath, et al. ${ }^{25}$ (1992) and Yeh, et al. ${ }^{8}$ (2004) demonstrated that OP-1 added to bone cell cultures enriched with osteoblasts at different stages of differentiation stimulates cell proliferation, collagen synthesis, induction of AP and osteocalcin synthesis. However, the effects of different concentrations of OP-1 at the cellular level have not been clearly defined.

The objective of the present study was to investigate whether primary cultured cells obtained from parietal bone of neonatal rats, called osteo-1, preserve their osteoblastic phenotype over serial passages or subcultures. In addition, the behavior of these cells cultured in the presence of different concentrations of rhOP-1 was analyzed.

\section{MATERIALAND METHODS}

The osteo-1 cell line was derived from the primary culture of calvaria of neonatal (1 to 4 days old) albino Wistar rats and obtained by enzymatic isolation, with the culture medium being supplemented with sodium $\beta$ glycerophosphate, ascorbic acid and dexamethasone after semi-confluence ${ }^{10}$. Subcultured and frozen cells from this cell line, previously identified and characterized by Deboni, et al. ${ }^{10}$ (1996), were used in the present experiments. All cells used in this study were kindly provided by the Laboratory of Cell Culture, Department of Dentistry, School of Dentistry, University of São Paulo, and the study was approved by the Ethics Committee of this Institution.

During the culture period, subcultured and frozen rat bone cells (osteo-1), primary human bone cells, called osteoAF cells, human pulp fibroblasts (FP5), mouse embryo fibroblasts (NH3T3), human gingival fibroblasts (FMM1) and canine kidney epithelial cells (MDCK) were maintained at $37^{\circ} \mathrm{C}$ in a humidified atmosphere containing $5 \% \mathrm{CO}_{2}$ and $95 \%$ atmospheric air. The culture media were changed every 2 days. After reaching subconfluence, the cells were enzymatically removed from the culture flasks using a solution of $1 \mathrm{nM}$ EDTA (Gibco, Life Technologies, Grand Island, NY, USA) and $0.25 \%$ trypsin (Gibco) and plated at a concentration of $2 \times 10^{4}$ cells/well onto 24-well culture plates $^{24}$ in the first and second experiment.

Three experiments were carried out in the present study: 1) characterization of subcultured and frozen rat bone cells (osteo-1), 2) analysis of the behavior of osteo-1 cells in two different culture media, and 3) determination of the effective concentration of OP-1.

To characterize osteo-1 cells as osteoblasts, osteo-1, NH3T3, FMM1 and MDCK cells were analyzed regarding total protein content and AP activity. NH3T3, FMM1 and MDCK were used as negative controls. The formation of calcified nodules was evaluated by staining with Alizarin red S. The cells were grown on DMEM (Sigma Chemical Co., St. Louis, MO, USA) supplemented with $10 \%$ fetal bovine serum (Cultilab, Campinas, SP, Brazil) and 1\% of an antibioticantimycotic solution (Sigma Chemical Co.).

In the second experiment for the evaluation of the behavior of osteo-1 cells in two different culture media, osteo1, osteo-AF, FP5 and FMM1 cultures were compared regarding total protein content and AP activity. The following culture media were used: $\alpha$-MEM (Gibco) supplemented with $10 \%$ fetal bovine serum (Gibco), $50 \mathrm{mg}$ / $\mathrm{mL}$ gentamicin (Gibco), $0.3 \mathrm{mg} / \mathrm{mL}$ fungizone (Gibco), $10^{-7} \mathrm{M}$ dexamethasone (Sigma), $5 \mathrm{mg} / \mathrm{l}$ ascorbic acid (Gibco) and 7 mM $\beta$-glycerophosphate (Sigma), called fully supplemented medium (FSM), and DMEM (Sigma) containing 10\% fetal bovine serum and $1 \%$ of an antibiotic-antimycotic solution.

After 7, 14 and 21 days of culture, total protein content in the culture was calculated according to the modified method of Lowry ${ }^{16}$ and AP activity was evaluated by the release of thymolphthalein monophosphate from thymolphthalein using a commercial kit (Labtest Diagnostica AS). At 14 and 21 days, adhered cells were fixed, dehydrated and processed for staining with Alizarin red $\mathrm{S}$, which stains calcium-rich areas ${ }^{3}$.

In the third experiment for the determination of the effective dose of OP-1, osteo- 1 cells were plated at a concentration of $5 \times 10^{2}$ cells/well onto 96 -well culture plates and treated with the following concentrations: 4, 10, 20, 50 and $100 \mathrm{ng} / \mathrm{mL}$ OP-1 (Sigma-Aldrich, St. Louis, MO, USA) added in DMEM containing 10\% fetal bovine serum. Cells cultured without rhOP-1 served as controls. Cell viability was calculated after 1, 3, 5 and 7 days by the MTT (3-(4,5dimethylthiazol-2-yl)-2,5-diphenyl tetrazolium bromide) method $^{21}$. The effect of treatment with OP-1 was assessed as follows: 1) osteo-1 cells were cultured in medium containing different concentrations of OP-1, with complete change of the medium every 2 days, and 2) cells were treated with different concentrations of OP-1 only on the first day of the experiment and cells were incubated without OP-1 and the medium was changed every 2 days throughout the study period.

Data were analyzed by analysis of variance and statistical significance was determined by the Tukey's test. A p value $<0.05$ was considered to be significant. 


\section{RESULTS}

\section{Characterization of osteo- 1 cells}

The AP activity/total protein content ratio differed between cell types (ANOVA: $\mathrm{F}=102.97$; d.f. $=3.6 ; \mathrm{p}=0.0000$ ), being higher for osteo-1 cells, and was affected by culture time (ANOVA: $\mathrm{F}=4.10 ;$ d.f. $=2.6 ; \mathrm{p}=0.02$ ), with a higher ratio being observed at 14 and 21 days (Figure 1). At 14 days, no production of mineralized matrix was observed for cultured osteo-1, NH3T3, MDCK or FMM1 cells, whereas at 21 days only subcultured and frozen osteoblasts (osteo-1 cells) showed positive Alizarin red S staining (Figure 2).

\section{Behavior of osteo-1 cells on FSM and DMEM}

Total protein content differed between bone cells and fibroblasts cultured on the two media (ANOVA: $\mathrm{F}=117.78$; d.f. $=7.4 ; p=0.0000$ ), with total protein being higher for osteo1 cells grown on DMEM at 21 days and for FMM1 cells grown on FSM after the same period. Total protein content was also affected by culture time (ANOVA: $\mathrm{F}=442.80$; d.f. $=2.4 ; \mathrm{p}=0.0000$ ), with $21>14=7$ days (Figure $3 \mathrm{~A}$ and $\mathrm{B}$ ).

$\mathrm{AP}$ activity differed between bone cells and fibroblasts cultured on the two media as follows (ANOVA: $\mathrm{F}=551.90$; d.f. $=7.4 ; \mathrm{p}=0.0000$ ): osteo- $1>$ osteo-AF $=$ FP5 = FMM1 when grown on DMEM; however, the same order was not observed when cells were grown on FSM. AP activity differed between osteo-1 and osteo-AF cells and was affected by

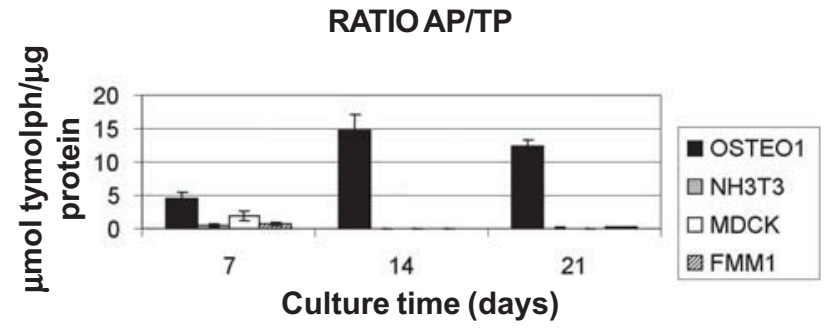

FIGURE 1- Alkaline phosphatase/total protein ratio $(\mu \mathrm{mol}$ thymolphthalein/ $\mu \mathrm{g}$ protein) obtained for the four different cell types after 7, 14 and 21 days of culture. Data are reported as the mean \pm standard deviation of one experiment performed in sextuplicate

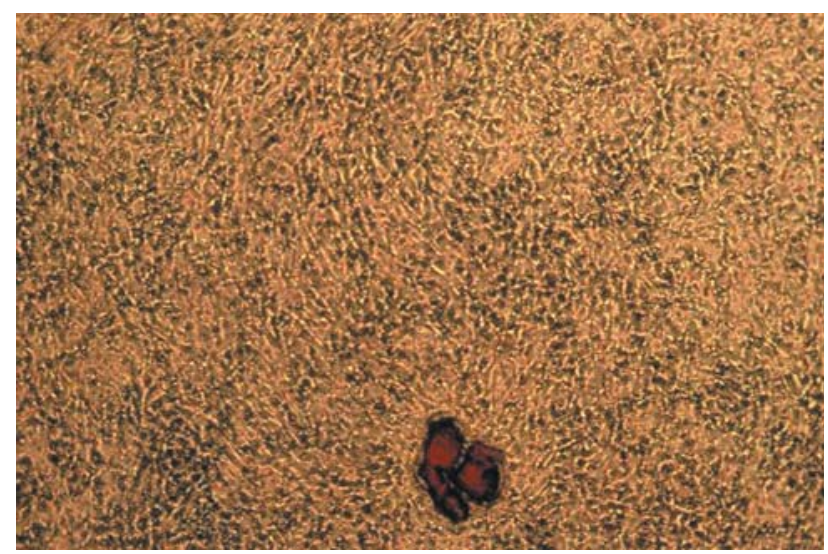

FIGURE 2- Photograph showing the formation of a bone nodule stained with Alizarin red $\mathrm{S}$ in an osteo-1 cell culture at 21 days culture time (ANOVA: $\mathrm{F}=46.51$; d.f. $=2.4 ; \mathrm{p}=0.0000$ ): osteo$\mathrm{AF}>$ osteo-1 $>$ FP5 $=$ FMM1, being higher after 21 days (Figure $4 \mathrm{~A}$ and $\mathrm{B}$ ).

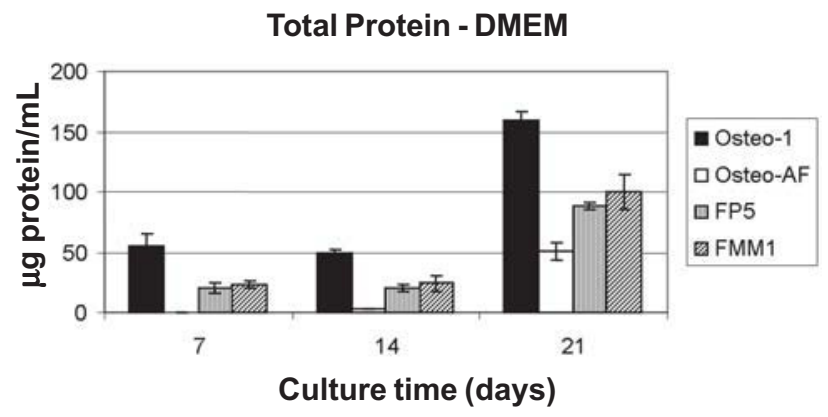

Total Protein - FSM

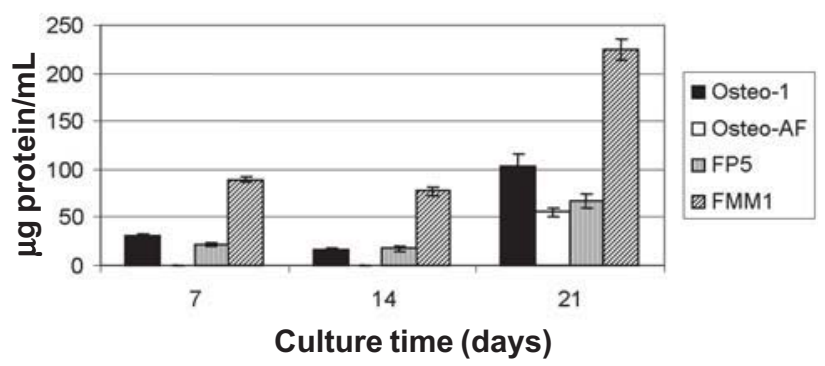

FIGURE 3- Total protein content $(\mu \mathrm{g} / \mathrm{mL})$ of bone cells and fibroblasts grown on DMEM (A) and FSM (B) after 7, 14 and 21 days of culture. Data are reported as the mean \pm standard deviation of one experiment performed in triplicate
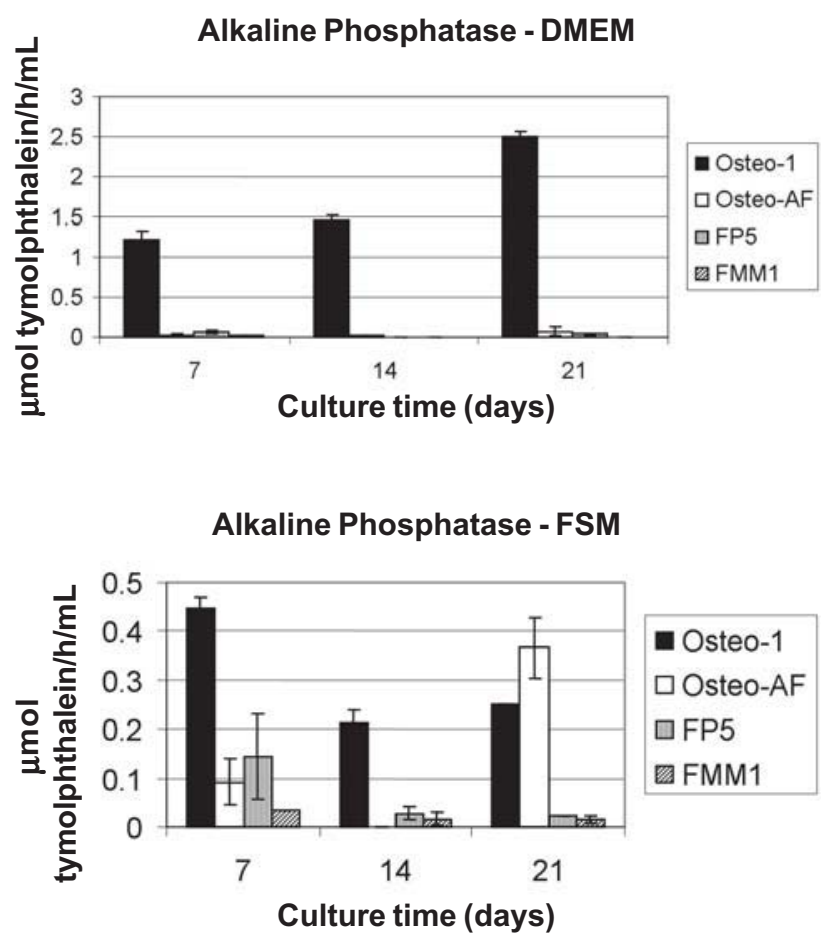

FIGURE 4- Alkaline phosphatase activity ( $\mu \mathrm{mol}$ thymolphthalein $/ \mathrm{h} / \mathrm{mL}$ ) of bone cells and fibroblasts grown on DMEM (A) and FSM (B) after 7, 14 and 21 days of culture. Data are reported as the mean \pm standard deviation of one experiment performed in triplicate 


\section{Effect of different concentrations of rhOP-1}

Cells treated with 10 and $20 \mathrm{ng} / \mathrm{mL}$ rhOP- 1 on the first day showed a significant increase in cell viability when compared to control. No significant difference between the control and treatment with $100 \mathrm{ng} / \mathrm{mL}$ rhOP-1 was observed at 1, 3 or 7 days (Figures 5 and 6 ).

The results showed a significant reduction in cell viability (ANOVA: $\mathrm{F}=131.32 ; \mathrm{df}=5.72 ; \mathrm{p}=0.0000$ ) between the control and groups treated with 4, 10,20 and $50 \mathrm{ng} / \mathrm{mL}$ rhOP-1 added to the medium every 2 days after 3,5 and 7 days (Figure 5).

When cells were treated with $4,10,20$ and $50 \mathrm{ng} / \mathrm{mL}$ rhOP-1 only on the first day of the experiment, cell viability decreased (ANOVA: $\mathrm{F}=13.81 ; \mathrm{df}=5.72 ; \mathrm{p}=0.0000$ ) compared to the control at 5 and 7 days (Figure 6).

\section{DISCUSSION}

Many biological events associated with bone healing can be investigated using isolated osteoblastic cells. In the present two experiments investigating the maintenance of the osteoblastic phenotype of osteo-1 cells subcultured and

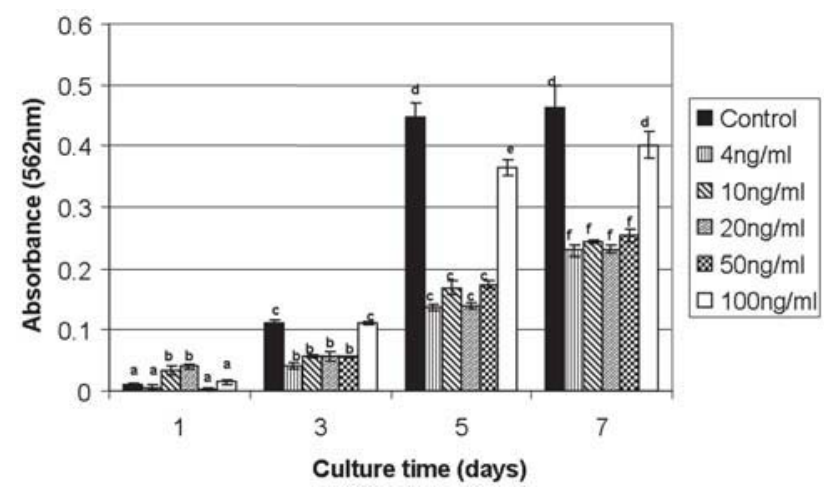

FIGURE 5- Cell viability (absorbance) of osteo-1 cells treated with five different concentrations of rhOP-1 in medium changed every 2 days after 1, 3, 5 and 7 days of culture. Data are reported as the mean \pm standard deviation of one experiment performed in quadruplicate

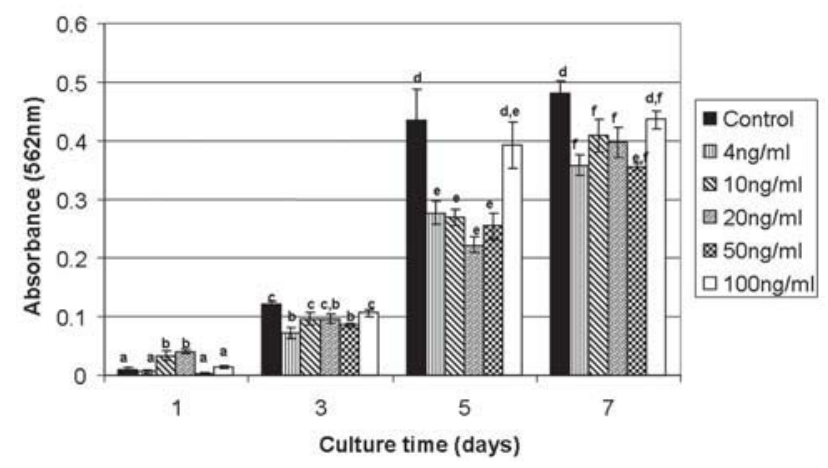

FIGURE 6- Cell viability (absorbance) of osteo-1 cells treated with different concentrations of OP-1 only on the first day of the experiment and cells incubated without OP-1, the medium being changed every 2 days, after 1, 3, 5 and 7 days of culture. Data are reported as the mean \pm standard deviation of one experiment performed in quadruplicate frozen over a period of 10 years, osteo- 1 cells showed mean AP activity levels ranging from 1.5 to $2.5 \mu \mathrm{mol}$ thymolphthalein $/ \mathrm{h} / \mathrm{mL}$ when grown on DMEM at 14 and 21 days. The specific time of expression of AP has been shown to coincide with the process of osteogenesis in the cell culture model described by Malaval, et al. ${ }^{17}$ (1994) and Beck $\operatorname{Jr}^{1}(2003)$.

Beloti, et al. ${ }^{3}$ (2005) demonstrated a mean AP activity of $0.73( \pm 0.07) \mu \mathrm{mol}$ thymolphthalein $/ \mathrm{h} / 10^{4}$ cells after the first passage of human bone marrow mesenchymal cells cultured on titanium. The authors also observed the formation of calcified nodules at 21 days.

Comparison of AP activity between the DMEM and FSM culture media revealed a significant increase for osteo- 1 cells grown on DMEM, and AP activity differed between osteo1 and osteo-AF cells grown on FSM. As the DMEM medium used was not supplemented with ascorbic acid, $\beta$ glycerophosphate or dexamethasone, osteo-AF cells were unable to differentiate. In the case of FSM, the presence of differentiation inducers permitted the expression of AP activity by osteo-AF cells. On the other hand, no increase in AP activity was observed for osteo-1 cells which had been induced previously.

AP activity has been associated with biological calcifications. In bone cell cultures, mineralization occurs after activation of AP. In the present study, calcium deposits demonstrated by positive Alizarin red S staining were only observed in osteo- 1 cultures at 21 days, a finding indicative of mineralization.

The present results showed that osteo- 1 cells produced significant amounts of total protein irrespective of the culture medium used or period analyzed. In the experiment for the characterization of osteo-1 cells, mean total protein content was $157.81 \mathrm{mg} / \mathrm{mL}$ at 14 days. In addition to AP activity, these data represent a complementary osteoblastic parameter since bone formation requires high levels of protein biosynthesis for the production of a protein matrix for mineralization.

The proliferative capacity of osteo-1 cells was higher on DMEM than on FSM. Mean total protein content was higher than $150 \mathrm{mg}$ protein $/ \mathrm{mL}$ at 21 days when cells were grown on DMEM, whereas mean total protein was significantly lower when cells were cultured on FSM (about $103 \mathrm{mg}$ protein $/ \mathrm{mL}$ ).

The specificity of the studied osteoblastic parameters was confirmed using fibroblast and epithelial cultures as negative controls in the experiments.

The results of the present study suggest that low concentrations of rhOP-1 (10 and $20 \mathrm{ng} / \mathrm{mL})$ stimulated osteo1 cell growth on the first day. The increase in cell viability was statistically significant for rhOP-1 concentrations of 10 and $20 \mathrm{ng} / \mathrm{mL}$ when compared to the control at the same time point, in agreement with Knutsen, et al. ${ }^{14}$ (1993), who observed elevated levels of AP activity for OP-1 concentrations ranging from 10 to $30 \mathrm{ng} / \mathrm{mL}$. Sampath, et al. $^{25}$ (1992) showed high levels of osteocalcin production when cells were grown in the presence of $25 \mathrm{ng} / \mathrm{mL}$ OP-1 and increased mineralization in osteoblast cultures treated 
with $20 \mathrm{ng} / \mathrm{mL}$ OP-1, suggesting that this concentration is a suitable and effective dose. Chaudhary, et al. ${ }^{6}$ (2004) and Yeh, et al. ${ }^{28}$ (2004) demonstrated that the osteogenic effect of OP-1 was determined by the time of treatment with OP-1. Therefore, we added OP-1 at every change of the culture medium.

Although Fernandes, et al. ${ }^{11}$ (1997) have shown that AP activity and the capacity to form mineralized areas decrease with successive passages, it is important to emphasize that even after a long period of induction with ascorbic acid, Bglycerophosphate and dexamethasone, osteo-1 cells continued to show the basic specific functions of osteoblasts, i.e., AP activity and ability of mineralization. The time of supplementation of the culture medium is probably an important factor for the induction of cell differentiation. Although Deboni, et al. ${ }^{10}$ (1996) observed that modifications of osteo-1 cells did not represent phenotypic changes or transformation of the culture able to originate a continuous or established cell line ${ }^{12}$ with a finite life cycle, i.e., cells undergoing senescence and death after some passages, laboratory observations over the 10 years of culture of these cells have shown that they behave like continuous cells showing a certain degree of uniformity and stability.

\section{CONCLUSIONS}

Subcultured and frozen osteo-1 cells showed an osteoblastic phenotype characterized by the presence of AP activity and calcified nodules and can be considered a viable lineage for the use in experiments. The DMEM culture medium seems to be able to sustain continuous culture of these cells and to support their differentiation and mineralization. The presence of low concentrations of OP-1 in the culture medium may promote an osteogenic effect that it is determined by the time of treatment with BMP.

\section{ACKNOWLEDGEMENTS}

The authors would like to thank Prof. Dr. Fernando Neves Nogueira, Department of Dental Materials, Prof. Dr. Adalberto Luiz Rosa and Prof. Dr. Marcio M. Beloti, Department of Oral and Maxillofacial Surgery, University of São Paulo, for their laboratory support and assistance with the cell culture tests and AP and TP measurements.

\section{REFERENCES}

1- Beck GR Jr. Inorganic phosphate as a signaling molecule in osteoblast differentiation. J Cell Biochem. 2003;90:234-43.

2- Bellows CG, Aubin JE, Heersche JNM, Antosz E. Mineralized bone nodules formed in vitro enzymatically released rat calvaria cell populations. Calcif Tissue Int. 1986;38:143-54.
3- Beloti MM, Bellesini LS, Rosa AL. The effect of purmorphamine on osteoblast phenotype expression of human bone marrow mesenchymal cells cultured on titanium. Biomaterials. 2005;26:42458

4- Beresford JN, Gallagher JA, Russell RGG. 1,25-hihydroxyvitamin D3 and human bone-derived cells in vitro. Effects of alkaline phosphatase, type I collagen and proliferation. Endocrinology. 1986;119:1776-85.

5- Canalis E, Economides AN, Gazzerro E. Bone morphogenetic proteins, their antagonists and the skeleton. Endocrine Reviews. $2003 ; 24: 218-35$

6- Chaudhary LR, Hofmeister AM, Hruska KA. Differential growth factor control of bone formation through osteoprogenitor differentiation. Bone. 2004;34:402-11.

7- Chavassieux PM, Chenu C, Valentin-Opran A, et al. Influence of experimental conditions on osteoblast activity in human primary bone cell cultures J Bone Miner Res. 1990;5:337-43.

8- Coelho MJ, Cabral AT, Fernandes MH. Human bone cell cultures in biocompatibility testing. Part I: osteoblastic differentiation of serially passaged human bone marrow cells cultured in á-MEM and in DMEM. Biomaterials. 2000;21:1087-94

9- Coelho MJ, Fernandes MH. Human bone cell cultures in biocompatibility testing. Part II: effect of ascorbic acid, bglycerophosphate and dexamethasone on osteoblastic differentiation. Biomaterials. 2000;21:1095-102.

10- Deboni MCZ, Jaeger MMM, Araújo NS. Development and characterization of osteoblast-like cell line. RPG. 1996;3:220-9.

11- Fernandes MH, Costa MA, Carvalho GS. Mineralization in serially passaged human alveolar bone cells. J Mater Science Mater Med. 1997;8:61-5.

12- Freshney RI. Culture of snimal cells. $4^{\text {th }}$ ed. New York: WileyLiss; 2000:577

13- Granjeiro JM, Oliveira RC, Bustos-Valenzuela JC, Sogayar MC, Taga R. Bone morphogenetic proteins: from structure to clinical use. Braz J Med Biol Res. 2005;38(10):1463-73.

14- Knutsen R, Wergedal JE, Sampath TK, Baylink DJ, Mohan S. Osteogenic protein-1 stimulates proliferation and differentiation of human bone cells in vitro. Biochem Biophys Res Commun. $1993 ; 194(3): 1352-8$.

15- Lavos-Valereto IC, Deboni MCZ, Azambuja N Jr, Marques MM. Evaluation of the titanium Ti-6Al-7Nb alloy with and without plasmasprayed hydroxyapatite coating on growth and viability of cultured osteoblast-like cells. J Periodontol.2002;73:900-5.

16- Lowry OH, Rosebrough NJ, Farr AL, Randall RJ. Protein measurement with the Folin phenol reagent. J Biol Chem.1951;193:265-75.

17- Malaval L, Modrowski D, Gupta Ak, Aubin JE. Cellular expression of bone-related proteins during in vitro osteogenesis in rat bone marrow stromal cell cultures. J Cell Physiol.1994;158:555-72.

18- Manduca P, Sanguineti C, Pistone M, Boccignone E, Sanguineti F, Santolini F, et al. Differential expression of alkaline phosphatase in clones of human osteoblast-like cells. J Bone Miner Res. 1993;8:291-300.

19- Maniatopolous C, Sodek J, Mecher AH. Bone formation in vitro by stromal cells obtained from bone marrow of young adult rats. Cell Tissue Res. 1988;254:317-30. 
20- Martinovic S, Borovecki F, Miljavac V, Kisic V, Maticic D, Francetic I, Vukicevic S. Requirement of a bone morphogenetic protein for the maintenance and stimulation of osteoblast differentiation. Arch Histol Cytol.2006;69(1):23-36.

21- Mosmann T. Rapid colorimetric assay for cellular growth and survival: application to proliferation and cytotoxicity assay. J Immmunol Meth. 1983;65:55-63.

22- Nijweide PJ, van Iperen-van Gent AS, Kawilararang- de Haas EW, van der Plas A, Wassernaar AM. Bone formation and calcification by isolated osteoblast-like cells. J Cell Biol.1982;93:318-23.

23- Reddy GK, Enwemeka CS. A simplified method for the analysis of hydroxyproline in biological tissues. Clin Biochem. 1996;29:2259 .

24- Rosa AL, Beloti MM. Rat bone marrow cell response to titanium and titanium alloy with different surface roughness. Clin Oral Implants Res. 2003;14:43-8.

25- Sampath TK, Maliakal J, Hauschka PV, Jones WK, Sasak H, Tucker RF, et al. Recombinant human osteogenic protein-1 (hOP-1) induces new bone formation in vivo with a specific activity comparable with natural bovine osteogenic protein and stimulates osteoblast proliferation and differentiation in vitro. J Biol Chemistry. 1992;267(28):20352-62.

26- Tenenbaum HC, Heersche JNM. Differentiation of osteoblasts and formation of mineralized bone in vitro. Calcif Tissue Int. $1982 ; 34: 76-9$.

27- Williams DC, Boder GB, Toomey RE, Paul DC, Hillman Jr CC, et al. Mineralization and metabolic response in serially passaged adult rat bone cells. Calcif Tissue Int. 1980;30:233-46.

28- Yeh L-CC, Tsai AD, Zavala MC, Lee JC. Cartilage-derived morphogenetic proteins enhance the osteogenic protein-1-induced osteoblsatic cell differentiation of $\mathrm{C} 2 \mathrm{C} 12$ cells. J Cel Physiology. 2004;201:401-8 